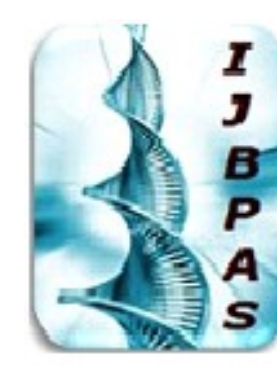

International Journal of Biology, Pharmacy and Allied Seiences (IJBPAS)

'A Bridge Betueen Caboratory and QRando'

WwW.ibpas.com

\title{
EXPLORING THE POTENTIAL OF BACTERIAL ISOLATE SHEWANELLA DECOLORATIONIS FOR DECOLORIZATION OF SULFONATED TEXTILE DYE DIRECT NAVY BLUE
}

\author{
SHETE U. R*, BHUKTAR J. J AND JADHAV A. G \\ Department of Microbiology, Govt. Institute of Science, Aurangabad (M.S.) - 431004
}

*Corresponding Author: Bhuktar J.J: E Mail: jaybhuktar@gmail.com

Received 28 ${ }^{\text {th }}$ May. 2020; Revised 30 ${ }^{\text {th }}$ June 2021; Accepted $7^{\text {th }}$ July 2021; Available online $1^{\text {st }}$ Oct. 2021 https://doi.org/10.31032/IJBPAS/2021/10.10.5653

\section{ABSTRACT}

Total six bacterial isolates (SL1, SL2, SL3, ST1, ST2 and ST3) were obtained from soil sample collected from two different local textile industries, Solapur. On the basis of qualitative screening for dye decolorization ST3 was found to decolorize nine structurally different textile dyes compared to other five (S11, SL2, SL3, ST1 and ST2) isolates hence it was selected for further studies. On the basis of \% dye decolorization isolate ST3 (75\%) found to be more effective in removing DNB (Direct Navy Blue) dye as compared to other dyes within $24 \mathrm{~h}$. Isolate ST3 showed maximum dye decolorization activity at Temperature $\left(30 \pm 2^{\circ} \mathrm{C}\right), \mathrm{pH}(7)$, inoculum size $(8 \% \mathrm{v} / \mathrm{v})$, dye concentration $(20 \mathrm{ppm}), 1 \%(\mathrm{w} / \mathrm{v})$ beef extract and nutrient broth medium whereas decolorization was not much influenced by static and shaking conditions. The isolate showed a positive correlation between growth and dye decolorization; hence it is biodegradation and not mere cell adsorption. The bacterial strain ST3 was identified by rDNA sequencing as Shewanella decolorationis.

Keywords: Screening, decolorization, dye Direct Navy Blue, optimum, Shewanella

\section{decolorationis}

\section{INTRODUCTION}

Synthetic dyes and colorants are being increasingly used these days by paper, textile, food, cosmetics, and pharmaceutical industries. Among these, textile industries are the largest consumer of dyes and pigments, accounting for $80 \%$ of total production. The inefficient dyeing process results in discharge of $10-15 \%$ of 
unused dye in waste water [19]. The textile industry discharges a large amount of colored wastewater causing a considerable environmental pollution [3]. Due to discharge of colored effluents into natural water bodies, the sunlight penetration is decreased which reduces both photosynthetic activity and dissolved oxygen concentration and disturbs ecology of water. Structural changes in red and white blood cells of fishes were recorded due to stress caused by such eco-toxic effluents [4]. Among industrial effluents, wastewater from textile and dyestuff industries is one of the most difficult to be treated. This is because industrial textile dyes have been purposely designed to be highly resistant to washing, chemical agents, solvents, and environmental factors such as action by sunlight. The synthetic and complex aromatic molecular structures of synthetic dyes also make them more stable and difficult to be degraded by microbial attack [16].

Bioremediation is the microbial clean up approach is on the front line and priority research area in the environmental sciences [15] though physical and chemical methods clean the textile wastewater efficiently, they are unsuccessful to provide a permanent solution due to high treatment cost, secondary pollution problems, and unable to remove recalcitrant azo dyes completely Therefore, in situ life forms from affected sites have fascinated researchers to utilize them for cleanup of the environment. These environment cleaners are well-adapted to the affected sites and sometimes use these pollutants as a source of nutrition. Use of microorganisms for the remediation purpose is an economic and eco-friendly way of textile dye degradation. Biological methods provide an eco-friendly approach but these methods also have some technical difficulties as far as in situ administration of pollutant is concerned. Modern approaches like use of bacteria, fungi, yeast and their combinatorial systems have proven to be effective for decolorization of dyes [9]. Several bacteria have obtained the capability of mineralizing chemical substances that were not at all present in the environment before the beginning of modern synthetic chemistry. Bacteria possess the ability to metabolize synthetic dyes by the action of various oxidative and reductive enzyme [2].

In the present study reported herein, bacteria were isolated from untreated textile industry soil and effluent. These isolates decolorized eleven structurally different synthetic dyes employed in the textile industries. The effect of various physicochemical parameters on decolorization of Direct Navy Blue (DNB) dye, with the efficient dye decolorizing isolate Shewanella decolorationis (ST-3) 
and also studied the correlation between growth and dye decolorization.

\section{MATERIALS AND METHODS}

Collection of effluent and soil sample as a source of dye decolorizing microorganisms was done from textile industry, MIDC area, Solapur (M.S.) India.

Dyes:

Dyes such as Acid Orange 63, Yellow M3R, Acid Red -1, Reactive Orange 11, Navy Blue F3R, Allura Red, Acid Blue 113, Blue HERD, Orange M2R, Red M5B, and Direct Navy Blue were purchased from the local market, MIDC Solapur.

Enrichment, screening and isolation of dye decolorizing bacteria:

The soil $1 \%(\mathrm{w} / \mathrm{v})$ and effluent $1 \%$ (v/v) samples collected from Solapur textile industry were inoculated in the respectively labeled $250 \mathrm{ml}$ Erlenmeyer flasks containing $50 \mathrm{ml}$ Nutrient Broth medium with Direct Navy Blue dye at 100ppm concentration. All the flasks along with control (without any inoculation) were incubated at $28 \pm 2^{\circ} \mathrm{C}$ for decolorization. Second enrichment was carried out same as the first one but by inoculating $1 \mathrm{ml}$ from first enriched flasks. Isolation of dye decolorizing microorganisms was carried on nutrient agar medium with 100 ppm DNB dye by streaking second enriched sample and by incubating at $28 \pm 2^{\circ} \mathrm{C}$ along with uninoculated plates as control till the isolated colonies showed zone of dye decolorization. Isolated pure cultures were maintained on nutrient agar slopes in the refrigerator at $4^{\circ} \mathrm{C}$.

\section{Dye Decolorization assay:}

Each isolated bacterial cultures were inoculated separately in nutrient broth medium containing DNB (100 ppm) and were incubated at $28 \pm 2^{\circ} \mathrm{C}$, under static condition for $24 \mathrm{~h}$. After $24 \mathrm{~h}$, aliquots ( $5 \mathrm{ml})$ of the culture media were withdrawn, centrifuged at $10,000 \mathrm{~g}$ for 10 minutes and the supernatant was used for analysis of decolorization by measuring the absorbance at maximum wavelength for the dye Direct Navy Blue $\left(\lambda_{\max }=575 \mathrm{~nm}\right)$ in the visible region on a double beam spectrophotometer. All the experiments were done in triplicates. The percentage of decolorization was calculated from the difference between initial and final values using the following formula.

$\%$ Dye Decolorization $=\mathbf{A}_{0}-\mathbf{A}_{\mathbf{t}} / \mathbf{A}_{0} \times 100$ $\mathrm{A}_{0}=$ Initial absorbance of control at the $\lambda_{\max }$ of dye

$A_{t}=$ Absorbance of treated sample after particular time interval

The bacterial strain giving maximum decolorization values was selected and used for further decolorization experiments.

\section{Analytical method:}

Absorbance of the supernatant withdrawn at different time intervals was 
measured at the maximum absorption wavelength for Direct Navy Blue $\left(\lambda_{\max }=575\right.$ $\mathrm{nm}$ ) in the visible region on a UV-Visible spectrophotometer. The percentage of decolorization was calculated from the difference between initial and final absorbance values.

Influence of various environmental parameters on dye decolorization:

The influence of various parameters such as static vs. shaking, aerobic vs. anaerobic conditions, $\mathrm{pH}(4-12)$, temperature $\left(30^{\circ} \mathrm{C}-60^{\circ} \mathrm{C}\right)$, different media, carbon sources (glucose, fructose and sucrose), inoculum size and dye concentration (10-100ppm) in the aqueous medium were studied by one variable at a time and also by Placket Burmann design.

Correlation between growth and dye decolorization:

Nutrient broth medium was inoculated with the culture suspension of Shewanella decolorationis and incubated on orbital shaker at $28 \pm 2^{\circ} \mathrm{C}$. Absorbance of growth and reduction in color was measured respectively at a wavelength of $600 \mathrm{~nm}$ and $575 \mathrm{~nm}$ at a time interval of $1 \mathrm{~h}$ for a period of 20 hours.

\section{RESULTS AND DISCUSSION}

Screening and isolation dye decolorizing bacteria:

Total six microorganism isolates showing zone of decolorization were obtained three isolates from each of two different textile industry effluents, collected from MIDC area, Solapur (M.S.).

\section{Dye Decolorization assay for selection of} a potent dye decolorizer:

Dye Decolorization assay was performed for the detection of ability of bacterium to decolorize eleven structurally different synthetic dyes (Some of these dyes with chemical structure are shown in Table $\mathbf{1}$ in Nutrient Broth medium containing each dye at 20 ppm concentration and results are shown in Table 2.

Amongst these isolates ST3 has decolorized nine dyes out of eleven dyes, whereas isolate SL1 decolorized three dyes (Reactive Orange 11, Orange M2R and RED M5B) whereas isolate SL2, ST1 (Allura red) and ST2, SL3, (RED M5B) decolorized only one dye. Isolate ST3 was found to be the most efficient microbial isolate based on its potency in decolorizing nine of eleven structurally different textile dyes as compared to other bacterial isolates. Hence, further studies were continued with ST3.

Identification of efficient dye decolorizing isolate:

Identification of the selected efficient dye decolorizer was done with $16 \mathrm{~S}$ rDNA sequencing and was identified as Shewanella decolorationis. Sequence submitted to GenBank and accession 
number(s) for it is SUB8930258 Seq1 MW513443.

Figure 1. Phylogenetic trees of the isolate ST3 based on 16S rRNA sequences plotted using MEGAX (10). The trees were constructed by using the neighbour-joining method. GenBank accession numbers are given in parentheses; the Sequence of this study represented in bold type.

The partial 16S rRNA sequence was obtained and compared with the database sequences using nucleotide blast program (https://blast.ncbi.nlm.nih.gov/Blast.cgi).

This showed significant similarity with Shewanella decolorationis (100\%). This was further compared with those of the type strains of 07 Shewanella species. The phylogenetic analysis showed that strain ST3 is most closely related to Shewanella decolorationis and Shewanella baltica. The comparision of $16 \mathrm{~S}$ rRNA gene sequences is not a sufficient criterion for species identity for some bacteria particularly for bacteria belongs to genera Bacillus, Vibrio, Pseudomonas, Aeromonas and Shewanella $(5,24,20,21,23)$. The biochemical and morphological characteristics along with the evolutionary tree based on $16 \mathrm{~S}$ rRNA confirms the isolate identification.

Influence of various environmental parameters on dye decolorization:

The influence of various parameters by using one variable at a time method on dye decolorization i.e., static vs. shaking, temperature, $\mathrm{pH}, \quad$ varying dye concentration, inoculum size, media components, different nutrient media and time course were undertaken.

Bacterial isolate ST-3 (Shewanella decolorationis) was chosen for further studies as mentioned above owing to its potency in decolorizing variety of textile dyes as compared to other bacterial isolates (SL1, SL 2, SL3, ST1 and ST2).

\section{Influence of static/shaking on} decolorization:

Oxygen has a significant effect on the physiological characteristics of the cells during the growth stages of cell. The presence of oxygen can either favor or inhibit the microbial degradation of azo dyes (17) The bacterial isolate Shewanella decolorationis decolorized Direct Navy Blue dye $(20 \mathrm{ppm}$ in Nutrient broth medium) efficiently under static condition (75\%) than shaking condition (100 rpm) (59 \%) decolorized in $24 \mathrm{~h}$ as shown in Figure 2.

Similar results were obtained by Saratale et al., 2012 [15] for decolorization of Remazol Red dye by Lysinibacillus sp. RGS under static condition (no aeration and agitation) $\quad 100 \%$ decolorization as compared to under shaking condition (100 rpm) $20 \%$ decolorization. Agarwal et al. 2014 [1], also reported that Providencia sp. decolorized more than 99\% Acid Black 210 dye under static condition within $24 \mathrm{~h}$, 
whereas only $9.36 \%$ decolorization in shaking condition even after $24 \mathrm{~h}$ of incubation. The results of study by Singh et al., 2014 [17] additionally proved that much of decolorization (85.52\%) of Acid Orange in static condition than under shaking condition (only $32.47 \%$ ) by the Staphylococcus hominis RMLRT03 strain.

There was no change in $\mathrm{pH}$ scale under static condition, indicating that dye decolorization was due to microbial action and not merely by change in $\mathrm{pH}$ [15].

From t- test for paired two sample analysis as shown in Table 3 it can be said that there is statistically significant difference in dye decolorization under shaking (mean=54.75, std dev. 2.99) and static conditions (mean $=75$, std. dev. 0.82) with $\mathrm{p}<0.05, \mathrm{n}=4$ after $24 \mathrm{~h}$ of incubation.

\section{Influence of temperature on dye decolorization:}

The results for effect of temperature on Direct Navy Blue dye decolorization by Shewanella decolorationis are shown in Figure 3. The maximum decolorization of Direct Navy Blue dye (77.24\%) was obtained within $24 \mathrm{~h}$ at ambient temperature $\left(28 \pm 2^{\circ} \mathrm{C}\right)$ followed by $37^{\circ} \mathrm{C}$ and $40^{\circ} \mathrm{C}$ $(73.07 \%$ and $72.06 \%)$ whereas at higher $60^{\circ} \mathrm{C}$ and lower $20^{\circ} \mathrm{C}$ temperature minimum decolorization $\mathbf{( 9 . 0 7 \%}$ and $15.52 \%$ respectively) was achieved. Further increase $\left(37,40\right.$, and $\left.50^{\circ} \mathrm{C}\right)$ or decrease $\left(20^{\circ} \mathrm{C}\right)$ in incubation temperature of $\left(28 \pm 2^{\circ} \mathrm{C}\right)$ resulted in reduction in the decolorization performance.

Influence of temperature on biodegradation of dyes might be associated with the microbial growth and enzymatic status of bacterial culture at respective conditions which determines its degradation abilities [12]. It may be because of the fact that microbial growth is temperature specific and dye decolorization is a biochemical reaction catalyzed by the enzymes, which are also affected by incubation temperature. The change in incubation temperature decreases or increases the enzyme activity and hence dye decolorization [2]. At higher temperature there was reduction in the dye decolorization because the enzymes involved in decolorization process were denatured at higher temperature hence its activity becomes lower [8]. According to Jadhav et al., 2013, [6] maximum potential of Pseudomonas sp. to decolorize Malachite green, Fast green, Brilliant green, Congo red, Methylene blue and Red BLI dye was noticed at $30^{\circ} \mathrm{C}$ which matches with our findings. In a similar way Agrawal et al., 2014 [1] reported that Providencia sp. SRS82 showed the best decolorization at $30^{\circ} \mathrm{C}$ for Acid Black 210 dye. Lade et al., 2015 [12] also has reported similar findings that the enhanced and maximum decolorization activity of dye RB 172 by bacterial culture 
Providenciarettgeri Strain HSL1 was observed at $30 \pm 0.2^{\circ} \mathrm{C}$ temperatures. Agrawal et al., 2014 [1] reported that Providencia $s p$. SRS82 exhibited maximum dye decolorization activity for dye Acid Black 210 at $30^{\circ} \mathrm{C}$ whereas lower and higher temperature than optimum have considerably decreased its decolorization rates.

\section{Influence of pH on dye decolorization:}

The textile effluent is not stable and consisting of crude mixture of dyes along with a number of chemicals and thus affects on treatment process. Activity of microorganisms over a broad range of $\mathrm{pH}$ can make them more suitable for degradation of dye pollutants [15]. Hence the effect of initial $\mathrm{pH}(4.0-11)$ on Direct Navy Blue dye decolorization by Shewanella decolorationis was investigated and results obtained were shown in Figure 4. The maximum percent dye removal was observed at neutral $\mathrm{pH} \quad 7 \quad(75 \%)$ as compared before and after $\mathrm{pH} 7$. Shewanella decolorationis showed around $30 \%$ decolorization at $\mathrm{pH} 5,6,8,9,10,11$ and 12 whereas at $\mathrm{pH} 4$ showed only $9.0 \%$ decolorization. Previous reports suggested that some other organism also showed better decolorization at $\mathrm{pH} 7$ compared to decolorization at acid and alkaline $\mathrm{pH}(2$, $18,4)$. The optimum $\mathrm{pH}$ was found to be 7.0 as also reported by Lade et al., 2015 for RB 172 by bacterial culture Providen ciarettgeri Strain HSL1 and a significant decrease in the decolorization performance was observed at lower $\mathrm{pH}(3-5)$ and higher $\mathrm{pH}$ (9-12). The transport of dye molecules across cell membrane has been known to govern by $\mathrm{pH}$ of the medium, which is considered as the rate limiting step in decolorization process.

\section{Influence of Inoculum size on dye decolorization:}

Experimental results on the estimation of inoculum size to achieve maximum decolorization are shown in Figure 5. The highest decolorization $81 \%$ occurred at an inoculum size of $8 \%(\mathrm{v} / \mathrm{v})$ in Nutrient Broth medium with DNB dye at concentration of $20 \mathrm{ppm}$. However, an inoculum size was not found to influence much the process of decolorization as the $\%$ dye decolorization ranged from $75 \%$ to $81 \%$ for inoculum size ranging from $1 \%$ to $10 \%$. No difference has been noticed at inoculum size of 5,6 , and $7 \%$ all showed $80 \%$ dye decolorization.

\section{Influence of Varying dye concentration on dye decolorization:}

In the present study effect of varying initial dye concentration ranging from 10-100 ppm on dye decolorization was investigated and results are shown in Figure 6. The decolorization efficiency of Shewanella decolorationis was found to be higher (78.10\%) with 10 ppm and $76.09 \%$, $64.71 \%$ respectively at 20 and $30 \mathrm{ppm}$ dye 
concentration, $58 \%$ at a concentration of $40 \mathrm{ppm}$ and around $40 \%$ at 50ppm, $60 \mathrm{ppm}$ and $70 \mathrm{ppm}$. The rate of dye decolorization found to be decreased with an increase in dye concentration from $10 \mathrm{ppm}$ to $100 \mathrm{ppm}$. This is probably due to the toxic effect of dye and accumulation of large quantity of dye metabolites after decolorization of high concentration of dye followed by their adverse effect onto the enzymes involved in decolorization [15]. Kurade et al., (2016) [11] also reported that the rate of the decolorization decreased with increasing in dye concentration $96 \%$ decolorization was obtained at $50 \mathrm{mgl}^{-1}$ within $48 \mathrm{~h}$ but complete decolorization was obtained at $10 \mathrm{gl}^{-1}$ within $72 \mathrm{~h}$. Similarly, Karunya et al., 2014 [8] observed that when decolourization was performed with different initial dye concentration $(10,20$, 30,50 and $100 \mathrm{mgl}^{-1}$ ), the rate of decolourization increased up to $20 \mathrm{mgl}^{-1}$ above which the decolourization rate started to decrease and has attributed this decrease in decolourization efficiency at higher dye concentrations due to the toxicity of the dye to bacteria.

\section{Influence of various media components} on dye decolorization:

The influence of various media components carbon sources (glucose, lactose, fructose, starch, sorbitol, and maltose) and nitrogen sources (beef extract, yeast extract, peptone, malt extract, and meat extract) at concentration $(1 \%(\mathrm{w} / \mathrm{v})$ each) on DNB dye decolorization by Shewanella decolorationis was studied and results are shown in Figure 7.

The use of various carbon sources has not shown much influence on dye decolorization because the $\%$ dye decolorization obtained for each was below $15 \%$ even after $96 \mathrm{~h}$.

However, the incorporation of nitrogen source has influenced the dye decolorization by Shewanella decolorationis with beef extract found to be the efficient nitrogen source showing more than $75 \%$ decolorization within $24 \mathrm{~h}$ followed by peptone (36.98\%), malt extract (24.6\%) and yeast extract (14.83\%). Whereas after $48 \mathrm{~h}$ the decolorization increased above of $80 \%$ for beef extract, $58 \%$ for peptone, $33 \%$ for malt extract and $50 \%$ yeast extract. After every $24 \mathrm{~h}$ a rise in dye decolorization was determined for each media components however highest dye decolorization was shown by beef extract incorporated set. Generally, complex organic nitrogen sources like peptone, beef extract, and yeast extract have more significant impact on DNB decolorizaiton than simple organic and inorganic nitrogen source.

According to Waghmode et al 2012 [21] glucose showed 93\% decolorization alone, however together with yeast extract and ammonium chloride, it showed 100\% and $93 \%$ decolorization of dye. This 
showed cooperative action of carbon and nitrogen sources in decolorization of Rubine GFL. Also, yeast extract and ammonium chloride showed $80 \%$ and $53 \%$ decolorization, [20]. In contrast to our results in which very less decolorization $(10 \%$ only) was observed when supplemented with carbohydrate as cosubstrate, Singh et al., 2014 showed that bacterial strain Staphylococcus hominis RMLRT03 showed maximum decolorization of Acid Orange in presence of carbon and nitrogen source as cosubstrate. Among completely different carbon sources tested for efficient decolorization of Acid Orange, glucose was found to be better carbon source with maximum decolorization (89.81\%) whereas fructose, sucrose and starchwere determined as poor carbon sources showing only $69 \% .98 \%, \quad 54.65 \%$, and $42.54 \%$ decolorization of Acid Orange dye, respectively. Singh et al., 2014 [17] also reported that the study on decolorization efficiency of Staphylococcus hominis RMLRT03 strain in the presence of different nitrogen source (yeast extract, peptone, ammonium sulphate and ammonium chloride) showed the maximum decolorization $(93.24 \%)$ in the presence of yeast extract, whereas in the presence of peptone, ammonium sulphate and ammonium chloride only 49\%.72\%, $64.19 \%$, and $36.97 \%$ respectively.
Similarly, Telke et al., 2008 [18] reported that yeast extract was effective cosubstrates for decolorization of Reactive Red 141 by Rhizobium radiobacter whereas in the present study with yeast extract the percent decolorization observed was around $50 \%$ after $48 \mathrm{~h}$ and more than $80 \%$ with beef extract.

\section{Influence of different Media on dye decolorization:}

The influence of various media like Basal medium, Basal liquid medium, Bushnell \& Hass medium, Mineral salt medium, Luria Bertani Broth (LBB) and Zhao and Zimmerman media (ZZM) on DNB dye decolorization by Shewanella decolorationis were studied and results are shown in Figure 8.

The maximumdye decolorization was observed in NB medium (75\%) followed by LB (60\%), MSM (37\%), BHM (33\%), BLM (27\%), BM (18\%) and least was shown by ZZM (only $2.3 \%$ ).

Correlation between growth of Shewanella decoloranationis and dye decolorization:

The correlation between growth of the organism and the percent dye decolorization was done in growth curve experiment. The results were noted after every hour and are shown in Figure 9. This experiment draws a relationship between growth of organism and its effect on dye decolorization. The maximum decolorization 
activity was observed in exponential phase of growth. The decolorization activity has been found to be less than $1 \%$ which is equivalent to no decolorization activity for first 3-4 h. Thereafter it got slowly increased till the end of exponential phase. This phenomenon of low decolorization activity may be reasoned with the explaination that the cells need some time to get adapted to the dye environment, once the dividing cells are adapted, they showed increase in decolorization with growth.

Bacillus subtilis HM showed color removal within the first $6 \mathrm{~h}$, during the exponential growth, whereas the remaining color was removed during the stationary phase of growth [13]. However in this study maximum dye removal was observed in exponential phase of growth. The decolorization was faster during the exponential growth phase of the microorganism and slowed down in the stationary phase. This is not unexpected, since the process must be dependent on cell biomass and on actively growing cells [14]. A study on Enterobacter sp. showed an initial rise in decolorization activity followed by fall before reaching stationary phase [7].

\section{Placket Burmann design for analyzing} influence of five different variables on dye decolorization:

Placket Burmann design experiment was set to understand the influence of five variables on dye decolorization by Shewanella decolorationis. The analysis of obtained results was done using Minitab software 19 which shown in the form of Pareto chart of the effects (Figure 10) and Normal plot of effects (Figure 11). From that it can be said that beef extract concentration and dye concentration are the major influencing and significant variables at a confidence level of $(\alpha=0.05)$ for dye decolorization.

Table 1: Some of the Synthetic dyes used for screening of potent dye decolorizer

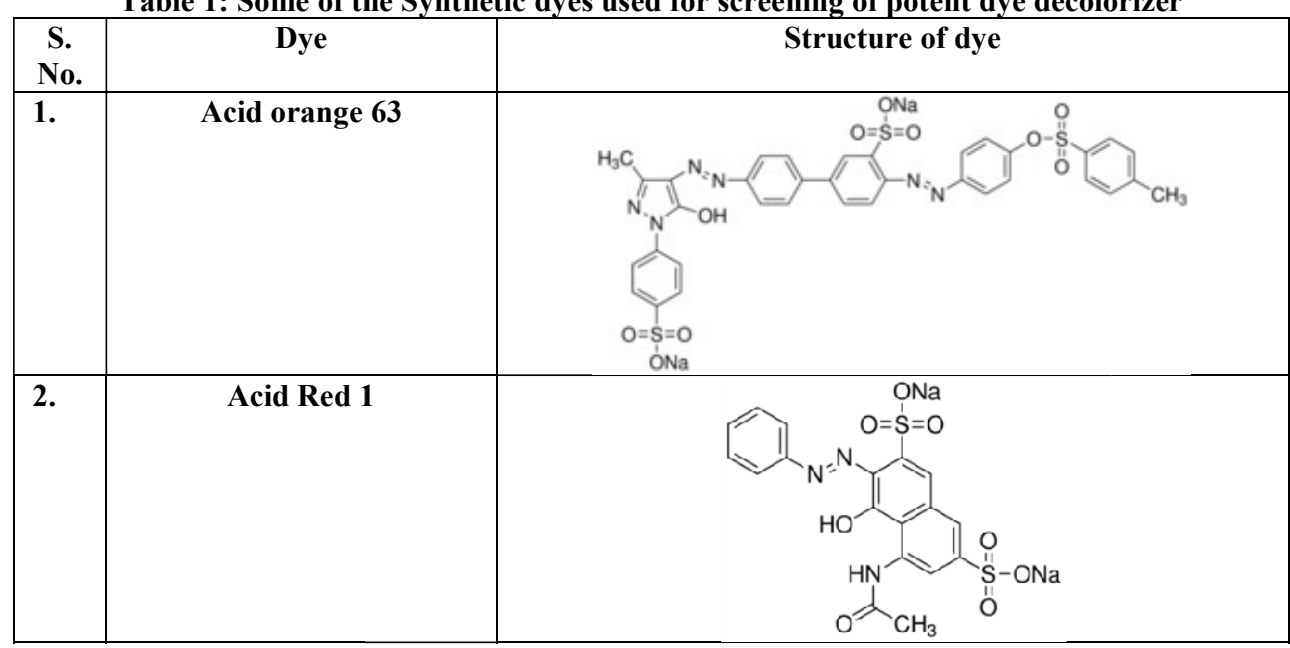




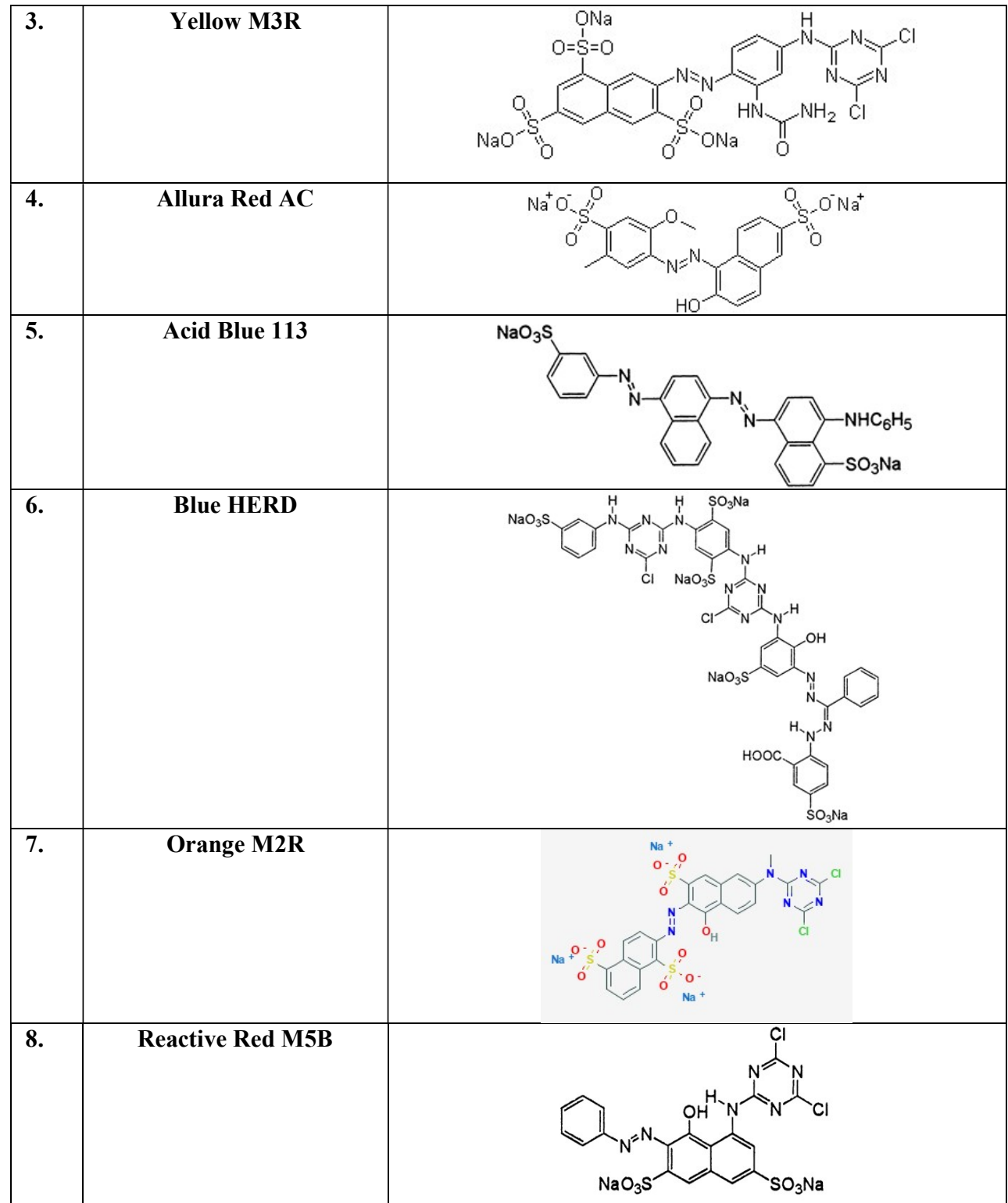

Table 2: Dye decolorization assay for selection of an efficient dye decolorizer $(-=$ no decolorization, $+=$ decolorizaiton)

\begin{tabular}{|c|c|c|c|c|c|c|}
\hline Name of dye & ST-1 & ST-2 & ST-3 & SL-1 & SL-2 & SL-3 \\
\hline Acid orange 63 & - & - & - & - & - & - \\
\hline Yellow M3R & - & - & + & - & - & - \\
\hline Acid Red -1 & - & - & + & - & - & - \\
\hline Reactive Orange 11 & - & - & + & + & - & - \\
\hline Navy Blue F3R & - & - & - & - & - & - \\
\hline Allura Red & + & - & + & - & + & - \\
\hline Acid Blue 113 & - & - & + & - & - & - \\
\hline Blue HERD & - & - & + & - & - & - \\
\hline Orange M2R & - & - & + & + & - & - \\
\hline Red M5B & - & + & + & + & - & + \\
\hline Direct Navy Blue & - & - & + & - & - & - \\
\hline
\end{tabular}




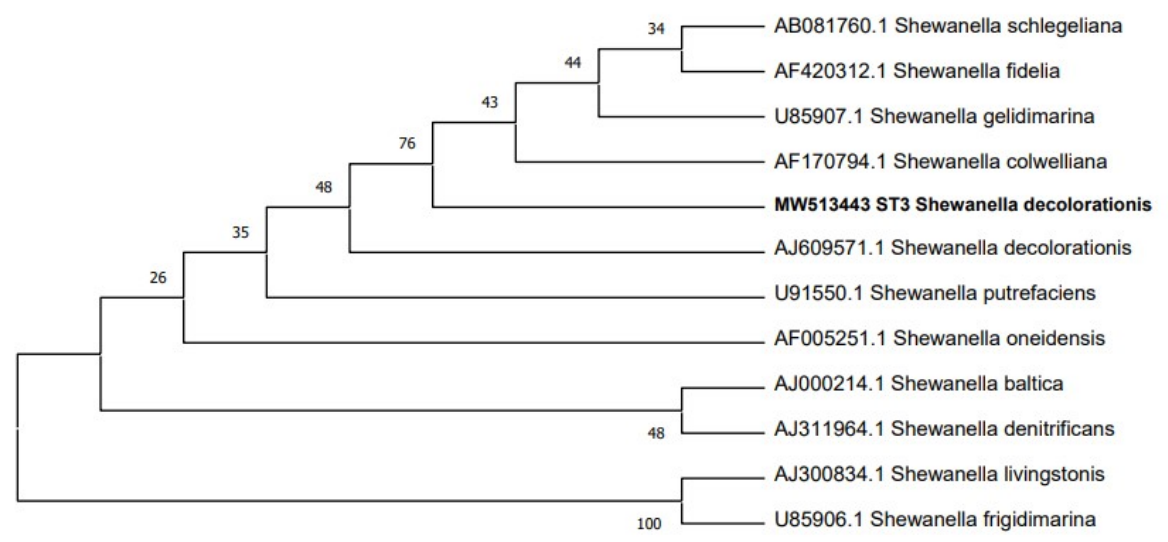

Figure 1: Phylogenetic trees of the isolate ST3 based on 16S rRNA sequences

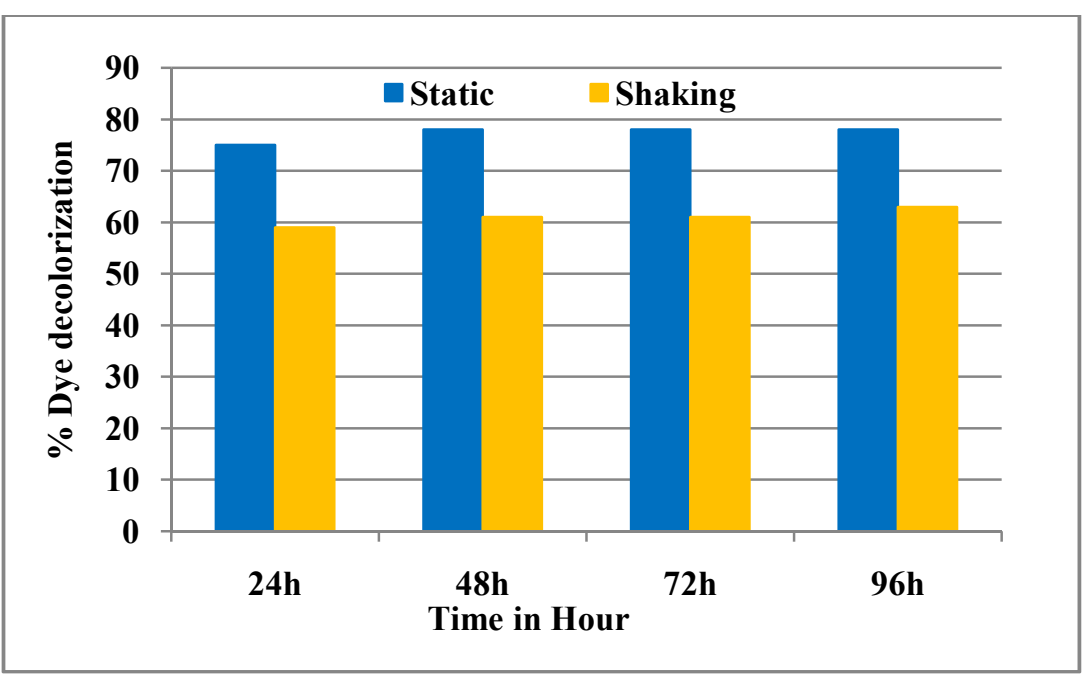

Figure 2: Influence of static and shaking condition on dye decolorization by ST3 N.B With DNB dye 20 ppm

Table 3: t-Test: Paired Two Sample for Means t-Test: Paired Two Sample for Means 24 hrs data

\begin{tabular}{|c|c|c|}
\hline \multicolumn{2}{|c|}{ t-Test: Paired Two Sample for Means } \\
\hline & & \\
\hline Mean & shaking & static \\
\hline Variance & $\mathbf{5 4 . 7 5}$ & 75 \\
\hline Observations & $\mathbf{8 . 9 1 6 6 6 7}$ & $\mathbf{0 . 6 6 6 6 6 7}$ \\
\hline Pearson Correlation & 4 & 4 \\
\hline Hypothesized Mean Difference & $\mathbf{0 . 9 5 7 0 2}$ & \\
\hline df & $\mathbf{0}$ & \\
\hline t Stat & 3 & \\
\hline P(T $<=$ t) one-tail & $\mathbf{- 1 8 . 2 6 5}$ & \\
\hline t Critical one-tail & $\mathbf{0 . 0 0 0 1 7 9}$ & \\
\hline P(T<=t) two-tail & $\mathbf{2 . 3 5 3 3 6 3}$ & \\
\hline t Critical two-tail & $\mathbf{0 . 0 0 0 3 5 8}$ & \\
\hline & $\mathbf{3 . 1 8 2 4 4 6}$ & \\
\hline
\end{tabular}




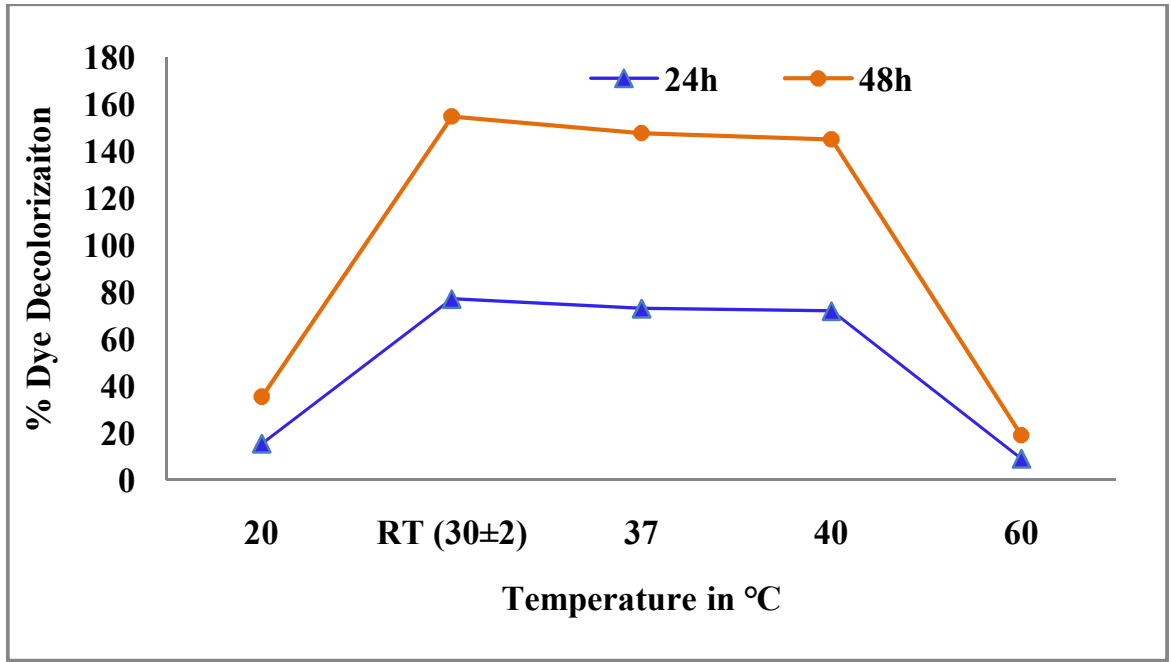

Figure 3: Influence of temperature on dye decolorization

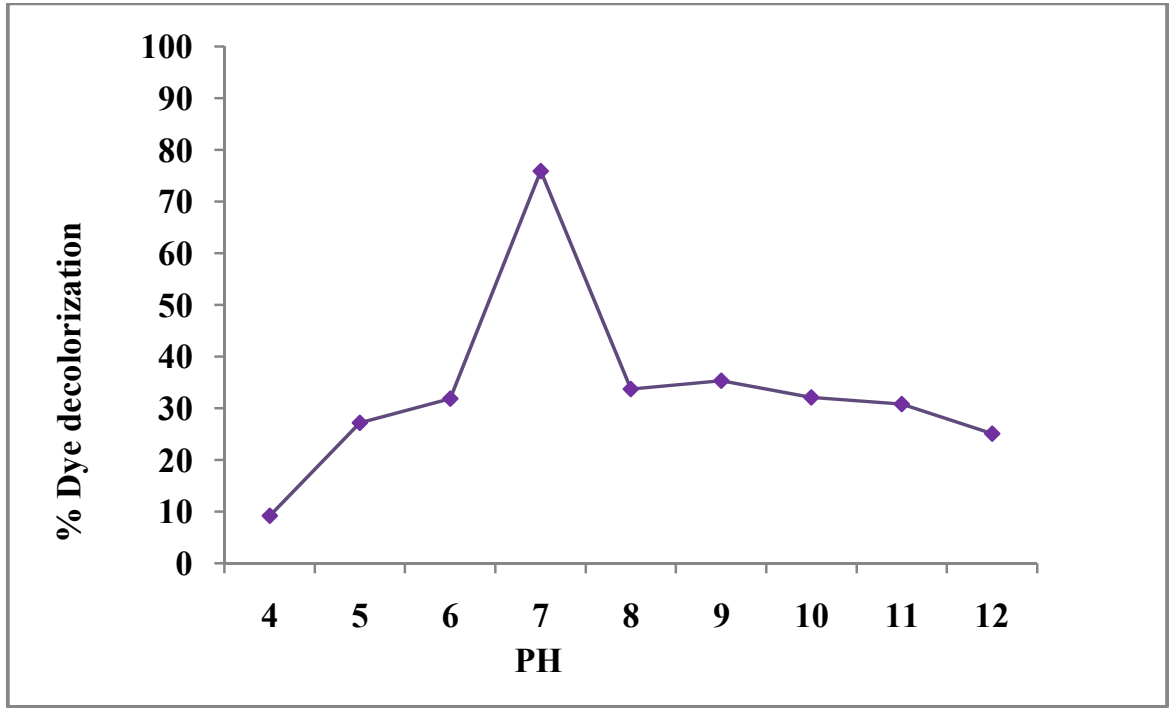

Figure 4: Influence of pH on dye decolorization

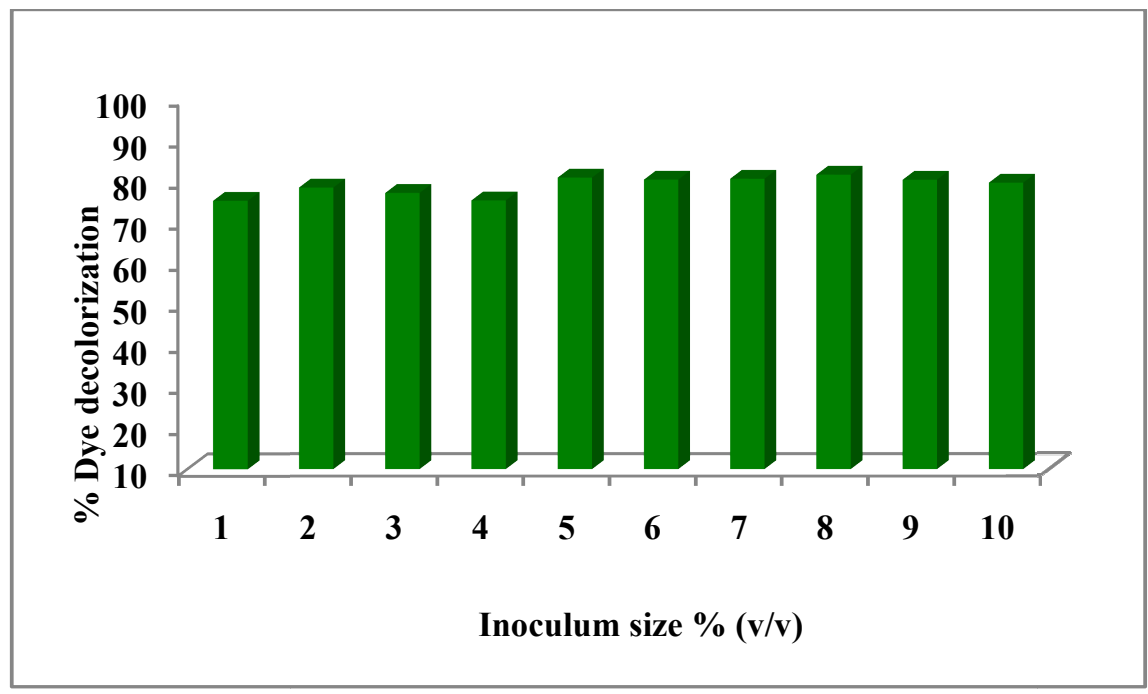

Figure 5: Influence of Inoculum size on dye decolorization 


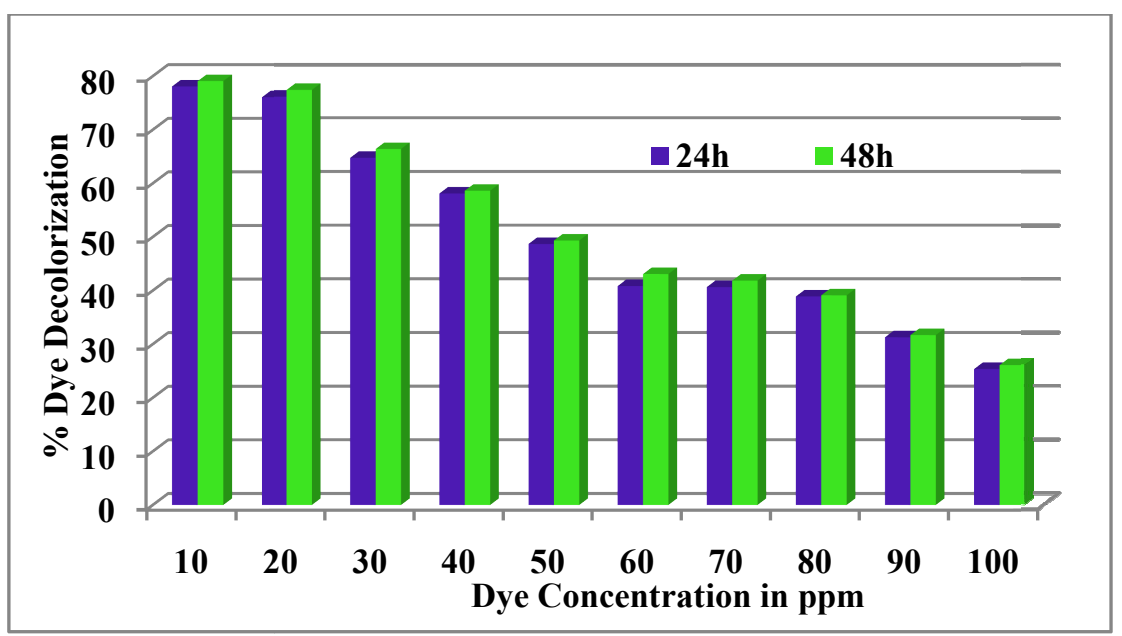

Figure 6: Influence of initial dye concentration on dye decolorization

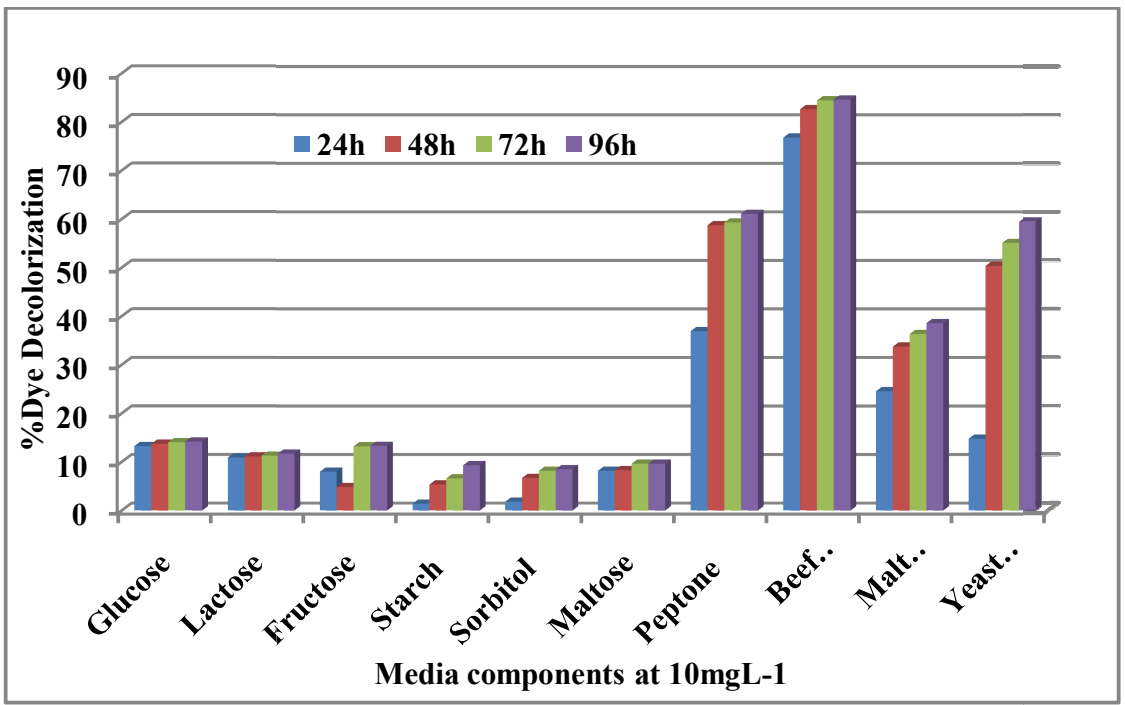

Figure 7: Influence of various media components on dye decolorization

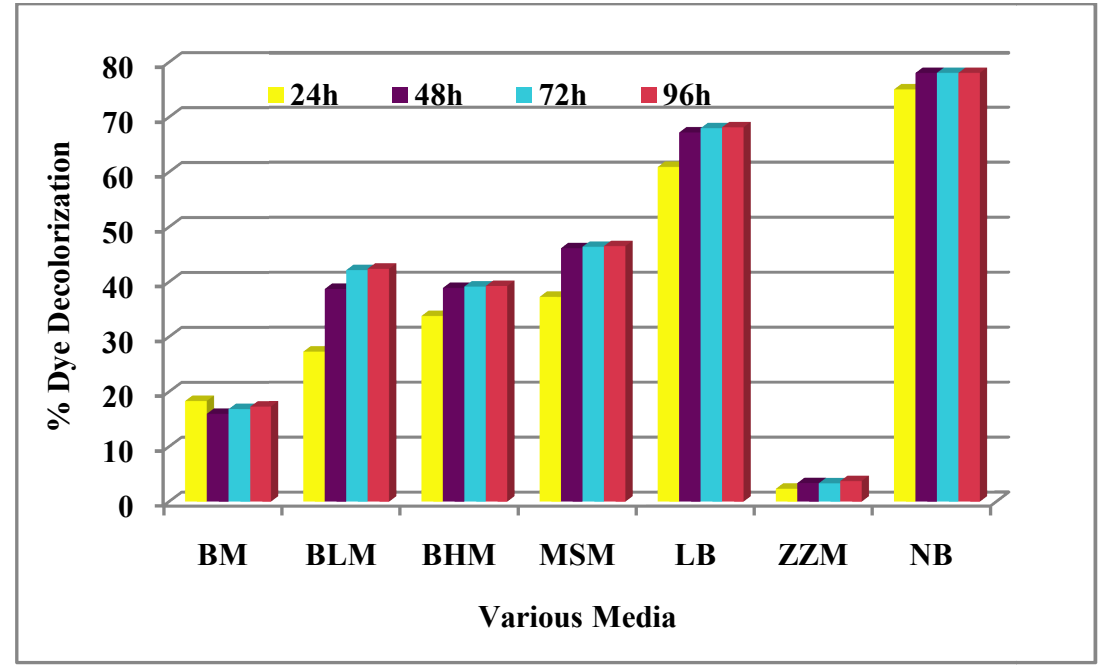

Figure 8: Influence of different Media on dye decolorization 


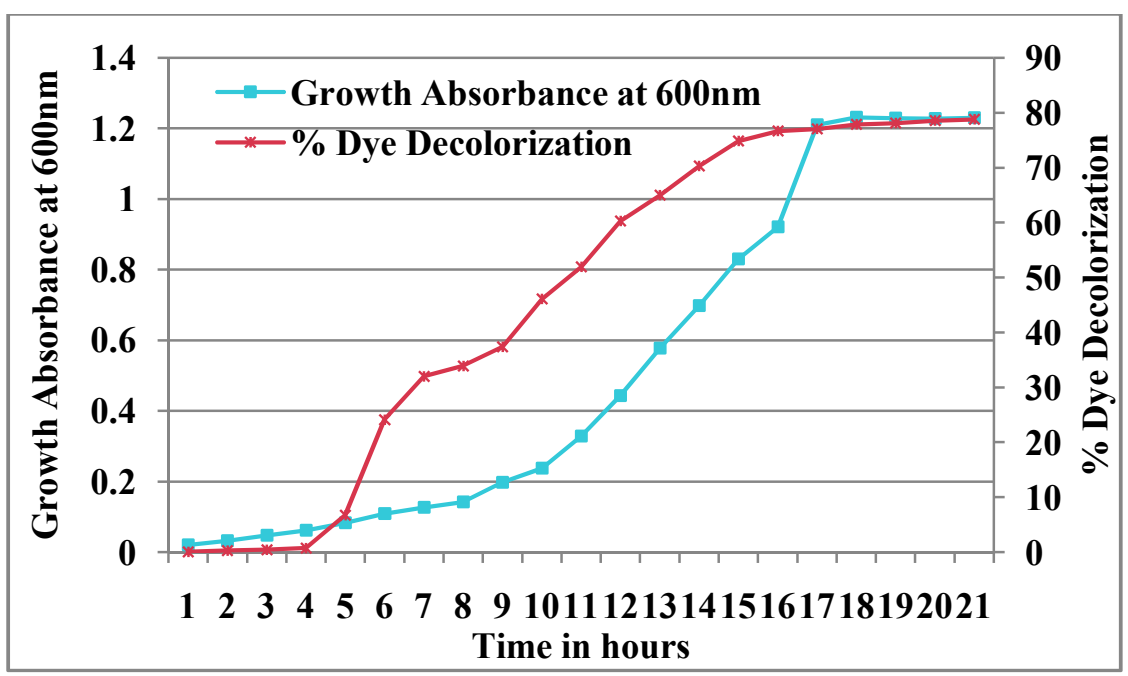

Figure 9: Correlation between growth of Shewanella decoloranationis and dye decolorization

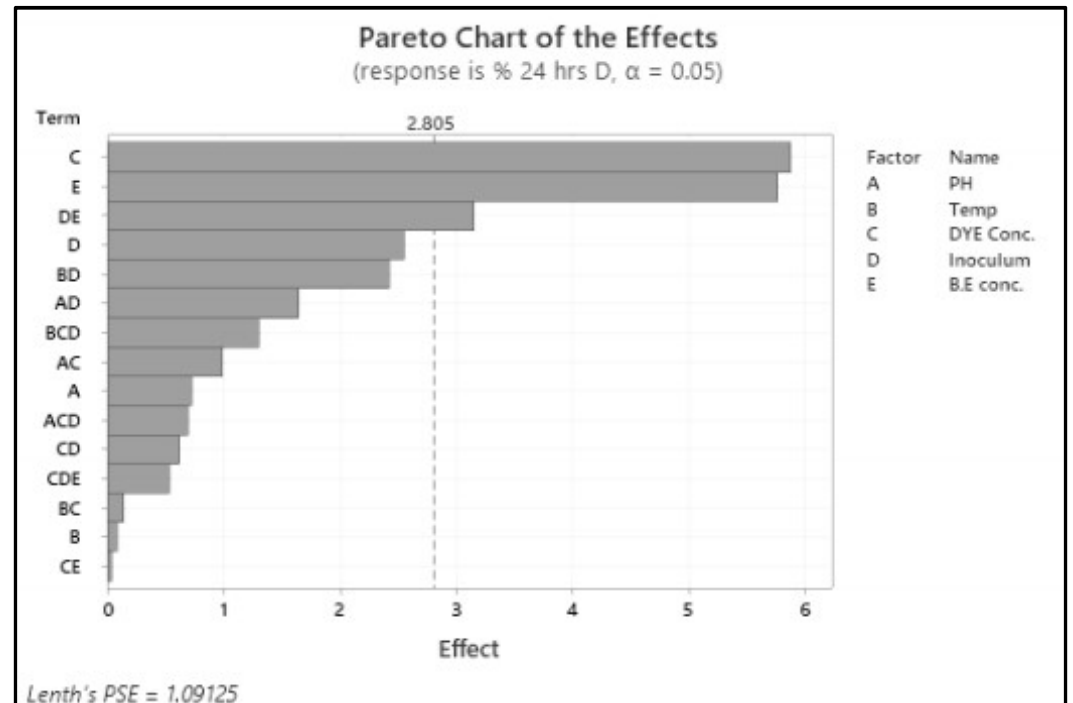

Figure 10: Pareto chart of effect of five different variables on dye decolorization

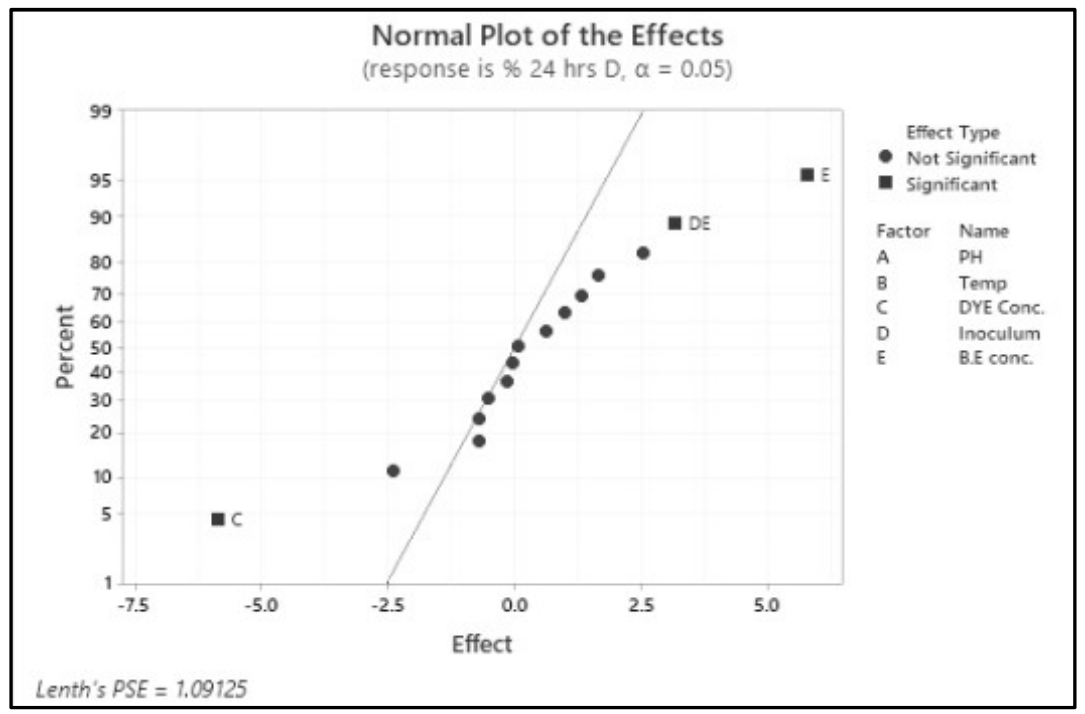

Figure 11: Normal Plot of effect of five different variables on dye decolorization 


\section{CONCLUSION}

The isolate Shewanella decolorationis (ST3) found to decolorize nine structurally different textile dyes and more effective in removing DNB (Direct Navy Blue) dye at temperature $\left(30 \pm 2^{\circ} \mathrm{C}\right)$, $\mathrm{pH}$ (7), inoculum size $(8 \% \mathrm{v} / \mathrm{v})$, dye concentration (20ppm), 1\%(w/v) beef extract and nutrient broth medium and its decolorization activity was not much influenced by static and shaking conditions. The isolate showed a positive correlation between growth and dye decolorization hence it is biodegradation and not mere cell adsorption. Therefore with further improvement studies on large scale Shewanella decolorationis can be employed for industrial dye waste removal effectively.

\section{REFERENCES}

[1] Agrawal, S., Tipre, D., Patel, B. and Dave, S. 2014. Optimization of triazo Acid Black 210 dye degradation by Providencia $s p$. SRS82 and elucidation of degradation pathway. Process Biochemistry. 49(): 110-119.

[2] Bedekar, P. A., Saratale R. G., Saratale, G. D., and Govindwar, S. P. Oxidative stress response in dye degrading bacterium Lysinibacillus sp. RGS exposed to Reactive Orange 16, degradation of RO16 and evaluation of toxicity. Environ
SciPollut Res.

DOI

10.1007/s11356-014-3041-2.

[3] Chaieb, K., Hagar, M. and Radwan, N. R. E. 2016. Biodegradation and decolorization of azo dyes by adherent Staphylococcus lentus strain KamelAppl Biol Chem. DOI 10.1007/s13765-016-0169-4

[4] Chougule, A. S., Jadhav, S. B. and Jadhav, J. P. Microbial Degradation and Detoxification of Synthetic Dye Mixture by Pseudomonas sp. SUK 1. Proc. Natl. Acad. Sci., India, Sect. B Biol. Sci. DOI 10.1007/s40011-014-0313-z

[5] Fox, G. E., Wisotzkey, J. D. \& Jurtshuk, P., Jr (1992). How close is close: 16S rRNA sequence identity may not be sufficient to guarantee species identity. Int $\mathrm{J}$ Syst. Bacteriol. 42, 166-170.

[6] Jadhav, S. B., Surwase, S. N., Phugare, S. S. and Jadhav, J. P.2013. Response surface methodology mediated optimization of Remazol Orange decolorization in plain distilled water by Pseudomonas aeruginosa $\mathrm{BCH}$ Int. J. Environ. Sci. Technol. 10:181-190. DOI 10.1007/s13762012-0088-9.

[7] Jirasripongpun, K., R. Nasanit, J. Niruntasook and B. Chotikasatian. Decolorization and Degradation of 
C. I. Reactive Red by Enterobacter sp. Thammasat Int. J. Sc. Tech., 12(4), 6-11, 2007.

[8] Karunya, A., Rose, C. and Nachiyar, C. V. 2014. Biodegradation of the textile dye Mordant Black 17 (Calcon) by Moraxella osloensis isolated from textile effluentcontaminated site. World J MicrobiolBiotechnol. 30: 915-924

[9] Khandare, R. V., Rane, N. R., Waghmode T. R. and Govindwar, S. P. 2012. Bacterial assisted phytoremediation for enhanced degradation of highly sulfonated diazo reactive dye. Environ SciPollut Res. 19:1709-1718. DOI 10.1007/s11356-011-0679-x.

[10] Kumar S., Stecher G., Li M., Knyaz C., and Tamura K. (2018). MEGA X: Molecular Evolutionary Genetics Analysis across computing platforms. Molecular Biology and Evolution 35:15471549.

[11] Kurade, M. B., Wahmode, T. R., Khandare, R. V., HunJeon, B. and Govindwar, S. P. 2016. Biodegradation and detoxication of textile dye Disperse Red 54 by Brevibacillus laterosporus and determination of its metabolic fate. $\mathrm{J}$. biosciences and bioengineering. 121(4): 442-449
[12] Lade, H., Govindwar, S. and Paul, D. 2015. Low-Cost Biodegradation and Detoxification of Textile Azo Dye C.I. Reactive Blue 172 by Providencia rettgeri Strain HSL1. Journal of Chemistry Vol. 2015, Article ID 894109, 10 pageshttps://doi.org/10.1155/2015/ 894109

[13] Mabrouk, M. E. M. and H. Yusuf. 2008. Decolorization of Fast Red by Bacillus Subtilis HM.Journal of Applied Sciences Research.4(3), 262-269.

[14] Ramalho, P. A., Scholze, H., Cardoso, M. H., Ramalho, M. T. and Oliveira - Campos, A. M. Improved conditions for the aerobic reductive decolourisation of azo dyes by Candida zeylanoides. Enzyme Microb. Technol, 31, 848-854, (2002).

[15] Saratale R. G., Gandhi, S.S., Purankar, M. V., Kurade, M. B., Govindwar, S. P., EunOh S. and Saratale G. D. 2012. Decolorization and detoxification of sulfonated azo dye C.I. Remazol Red and textile effluent by isolated Lysinibacillus sp. RGS. $\mathrm{J}$. biosciences and bioengineering. 115 (6): 658-667

[16] Shuib, F. N. S., Husaini, A., Zulkharnain, A., Roslan, H. A., 
and Guan, T. M. 2016.

Optimization of physiochemical parameters during bioremediation of synthetic dye by Marasmius cladophyllus UMAS MS8 using statistical approach. The Scientific World Journal Volume 2016, Article ID 8296239, 7 pages http://dx.doi.org/10.1155/2016/82 96239.

[17] Singh, R. P., Singh, P. K. and Singh R. L. 2014.Bacterial Decolorization of Textile Azo Dye Acid Orange by Staphylococcus hominis RMLRT03.Toxicol Int. 21(2): 160-166.

[18] Telke A, Kalyani D, Jadhav J, Govindwar S. 2008. Kinetics and mechanism of reactive red 141 degradation by a bacterial isolate Rhizobium radiobacter MTCC 8161. Acta. Chim. Slov. 55: 320-9

[19] Thakur, J. K., Paul, S., Annapurna, K., Padaria, J. C. and Gopal, M. 2014. Degradation of Sulphonated Azo Dye Red HE7B by Bacillus sp. and Elucidation of Degradative pathways. Curr. Microbiol. DOI 10.1007/s00284-014-0571-2

[20] Venkateswaran, K., Moser, D. P., Dollhopf, M. E. \& 10 other authors (1999). Polyphasic taxonomy of the genus Shewanella and description of Shewanella oneidensis sp. nov. Int J Syst. Bacteriol. 49, 705-724.

[21] Waghmode, T. R., Kurade, M. B., Lade, H. S. and Govindwar, S. P. 2012. Decolorization and Biodegradation of Rubine GFL by Microbial Consortium GG-BL in Sequential Aerobic/ Microaerophilic Process. Appl. Biochem. Biotechnol. 167: 1578-1594. DOI 10.1007/s12010-012-9585-Z

[22] Ya'ñez, M. A., Catala'n, V., Apra'iz, D., Figueras, M. J. and Martı'nez Murcia, A. J. (2003). Phylogenetic analysis of members of the genus Aeromonas based on gyrB gene sequences. Int $\mathrm{J}$ SystEvolMicrobiol 53, 875-883.

[23] Yamamoto, S. and Harayama, S. (1995). PCR amplification and direct sequencing of gyrB genes with universal primers and their application to the detection and taxonomic analysis of Pseudomonas putida strains. Appl Environ Microbiol 61, 1104-1109. 